\title{
Move Analysis of Master's Thesis and Dissertation Abstracts in English and Indonesian
}

\author{
Syifa Nanda Pratiwi ${ }^{1,}$ Eri Kurniawan ${ }^{1}$ Wawan Gunawan ${ }^{1}$ Arif Husein Lubis ${ }^{2}$
}

\author{
${ }^{1}$ English Education Department, Universitas Pendidikan Indonesia \\ ${ }^{2}$ Korean Education Department, Universitas Pendidikan Indonesia \\ ${ }^{*}$ Corresponding author. Email: syifananda@upi.edu
}

\begin{abstract}
Move Analysis is an analytical approach to text identification and has been used to evaluate various types of genres, such as academic paper, thesis, essay, etc. However, research that focuses on the manifestation of abstract discourse patterns in master's theses and doctoral dissertation has not been widely carried out. This study aims to identify the abstract discourse patterns in master's theses and doctoral dissertations and its linguistic features realization that are displayed in each final paper. Using Hyland's (2000) five-move analysis model, this study analysed the abstracts of final papers in English and Indonesian. Differences were found in the frequency of occurrence in each move. In terms of linguistic features realization, the English and Indonesian data showed significant differences in tense usage. However, voice and verb usage in each language and level of abstracts have shown notable similarities of occurrences. These findings are expected to produce a clearer picture of differences in the manifestation of abstract discourse patterns in each language. Further comparative research on this particular topic with more subjects of data is suggested.
\end{abstract}

Keywords: Abstract discourse pattern, linguistic features realization, move analysis

\section{INTRODUCTION}

The ability to effectively write the abstracts of a research article (hereafter RA) becomes increasingly crucial when it is aimed to be published in international and reputable journals (Kurniawan, Lubis, Suherdi, \& Danuwijaya, 2019). Abstract in research paper is a measure of appropriateness which is often the main and first consideration for journal editors to accept or reject an article. Abstracts are worth of study because they are significant carriers of a discipline's epistemological and social assumptions, and therefore a rich source of interactional features that allow us to see how individuals work to position themselves within their communities (Hyland, 2000, 2004). They must appeal to readers of one disciplinary discourse. Writing research article abstracts for the purpose of international publication does not recognize different levels of difficulty because there is already a common global agreement and rules governing how to write good and acceptable research abstracts.

Move analysis is an analytical approach to text identification (Swales, 1990, 2004, as cited in Amnuai, 2019 b, p. 162) and has been used to evaluate various types of genres, such as academic paper, thesis, essay, etc. Move analysis can be described as a textual analysis of the communicative goals and their constituent steps to explain how the discourse pattern is manifested in the writing being investigated. A move is a unit relating to both the writer's purpose and the extent to which they wish to convey their message or meaning (Nikpei, 2016). This communicative goal can be realized in the form of sentences, paragraphs, or several sentences and paragraphs. In other words, for example, if the communicative goal of the writer is to describe the research method, several constituent steps need to be considered, such as conveying information about research subjects, research instruments, and research data analysis procedures. Based on this definition, rhetorical move analysis can be interpreted as a textual analysis of communicative objectives and their constituent steps to understand how the discourse pattern is manifested in the writing that is being analyzed (Zamani \& Ebadi, 2016). In addition, the method of discourse pattern analysis aims to determine the trends in the practice of certain writing styles and the variations that appear between the texts being analyzed.

There has been a lot of research that focuses on Rhetorical Move Analysis. They usually came in three contexts. The first one is analysis that involves only one scientific discipline (Amnuai, 2019b). The second one is 
analysis that compares more than one discipline's rhetorical move structure to see the difference between several disciplines (Amnuai, 2019a; Nikpei, 2016; Suntara \& Usaha, 2013; Vathanalaoha \& Tangkiengsirisin, 2018). Lastly, researchers tried to compare abstracts discourse patterns by writers with various backgrounds, such as mother tongue (Mohsenzadeh, 2013; Xiao \& Cao, 2013; Zamani \& Ebadi, 2016), academic writing proficiency level or region. Previous studies mostly analysed abstract discourse patterns in scientific works, which were mostly taken from student undergraduate theses (Male, 2018; Suryani \& Rismiyanto, 2019), but not many studies have focused on the manifestation of abstract discourse patterns in master's theses and dissertations of lecturers who have doctoral degrees.

Besides rhetorical move structure, studies of linguistic features in RA abstracts have provided much insight into the genre (Zhang, et al., 2012, as cited in Amnuai, 2019b, p. 162). The linguistic features such as voice, verb, and tense are widely studied. For example, Amnuai (2019b) found that the most frequently used tense in abstracts of Theses and RAs was the present simple. Moreover, action voice was used frequently in the RAs while most Theses opted to present their Method and Product moves in the passive form.

This study aims to identify the abstract discourse patterns in master's theses and doctoral dissertations and its linguistic features realization that are displayed in each final paper. This study also aims to compare and identify whether there are differences between abstracts written in English and Indonesian. Using Hyland's (2000) five-move analysis model, the findings from this study are expected to produce a clearer picture of differences in the manifestation of abstract discourse patterns between English and Indonesian abstracts. These findings could uncover the characteristics of each language which could help students to write their abstracts since this study reveal the similarities and differences between the two datasets. In addition, the findings of this research can help in the field of teaching and learning when writing an abstract. The following section is the theoretical foundation of this study. It encompasses the typology of an RA abstract and the rhetorical move structure.

\section{METHOD}

\subsection{Research Design}

This research used a comparative qualitative design. This is in accordance with the objectives of this study, namely, to analyse and compare the quality of abstract discourse patterns in English and Indonesian from the master's theses and dissertations of lecturers at the Universitas Pendidikan Indonesia and their language realization. The comparison of linguistic realizations focused on tense, voice, and verb of each move. Hyland's (2000) model of abstract discourse pattern was adopted to analyse the quality of abstract discourse patterns from master's theses and dissertations written by lecturers at the University of Education of Indonesia. Hyland's (2000) model, as shown in Table 1, is therefore the most appropriate model for this analysis.

Table 1. Move Analysis Guideline from Hyland's (2000) Model

\begin{tabular}{cccc}
\hline & Move & & Step \\
\hline & & S1 & Arguing for topic significance \\
M1 & Introduction & S2 & Making topic generalization \\
& & S3 & Defining the key term(s) \\
M2 & Purpose & S4 & Identifying Gap \\
& & S1 & Stating the research purpose \\
M3 & Method & S2 & Describing participants/data sources \\
& & S3 & Describing procedure and context \\
M4 & Findings & & $\begin{array}{c}\text { Describing the main results } \\
\text { Deducing conclusion }\end{array}$ \\
& & S1 & Dedument(s) \\
M5 & Conclusion & S2 & Evaluating the significance of the \\
& & S3 & research \\
& & S4 & Presenting recommendation or \\
& & & implication \\
\hline
\end{tabular}

\subsection{Data Source}

In order to analyse the differences in discourse patterns and their linguistic features realization, two sets of abstracts were compiled. The first set of abstracts consists of two scientific work abstracts written in English. The two abstracts were taken from one of the English Linguistic and Literature lecturer's master's thesis and dissertation. The second set of abstracts consists of two scientific work abstracts written in Indonesian. The two abstracts were taken from one of the Indonesian Linguistic and Literature lecturer's master's thesis and dissertation. The selection of the samples is based on the criteria of lecturers who have obtained master's and doctoral degrees in Indonesia.

\subsection{Data Analysis}

For research on abstract discourse patterns, this study used a textual approach because the results obtained were various organizational structures of discourse patterns and their language realization so that it focused on what is stated in the abstract. Abstracts written in English were assigned as E1 and E2, while abstracts written in Indonesian were assigned as I1 and I2. 1 refers to master's theses and 2 refers to dissertations. Data that had been analysed manually using the Hyland's (2000) model were transferred to Excel to make it easier for researchers to find trends and variations in the emergence of abstract discourse patterns in each type of scientific work. The same process was carried out to determine trends and variations in the realization of the language. 


\section{FINDINGS AND DISCUSSION}

As the main aims stated above, the results of the present study are specifically aimed to uncover the characteristics of English and Indonesian which could help students write their abstracts. This section includes the results concerning the rhetorical move structure and its linguistic features realization. Some important points have been addressed and discussed.

\subsection{Move and Step Occurrences}

The findings discussed in this subsection point to rhetorical moves. It is noted that the realization of certain movements or features is exemplified, and the reference sources are given after each example. Thus, E1 and E2 refer to abstracts of master's thesis and dissertation written in English, and I1 and I2 refers to abstracts of master's thesis and dissertation written in Indonesian.

Table 2. The Frequency of Occurrences of Moves in Each Abstract

\begin{tabular}{ccccc}
\hline Move & E1 & E2 & I1 & I2 \\
\hline M1 & $25 \%$ & $33 \%$ & - & $19 \%$ \\
M2 & $8 \%$ & $4 \%$ & $8 \%$ & $6 \%$ \\
M3 & $17 \%$ & $13 \%$ & $58 \%$ & $38 \%$ \\
M4 & $33 \%$ & $25 \%$ & $17 \%$ & $31 \%$ \\
M5 & $17 \%$ & $25 \%$ & $17 \%$ & $6 \%$ \\
\hline
\end{tabular}

Table 2 shows similarities and differences in the occurrences of moves. In both abstracts written in English, the Introduction and Findings moves were the most frequently occurred. However, in abstracts written in Indonesian, Method move was the frequent move. The most noticeable differences were in the use of Introduction and Method move. In both master's thesis and dissertation abstracts written in English, Introduction moves occurred the most, while abstracts written in Indonesian did not use the move frequently. Moreover, in master's thesis written in Indonesian, Introduction move was not used at all. This could mean that the author of abstracts written in Indonesian did not focus on the established context of the paper as much as the information on design, procedures, assumptions, approach, and data that comes in the Method move.

The proportion of each manifested step received little consideration in previous research, as the majority were more concerned about the salience of the moves. (Hardjanto, 2017; Kafes, 2012; Pho, 2008 as cited in Kurniawan et al., 2019). As a result, this research sheds light on the explanation of the occurrence of move in each abstract.

Table 3 shows the frequency of occurrences of steps in each move. As stated above, for abstracts written in English, M4 is the most manifested move. This could indicate the author's intention to emphasize the product of his/her research. However, Conclusion move does not have any steps. In abstracts written in Indonesian, however, Method move frequently occurred mostly in Step 3- Describing product and context. Interestingly, both sets of abstracts show similarities in Move 1, Step 1Arguing for topic significance, Step 3- Defining key $\operatorname{term}(s)$; Move 5, Step 2- Evaluating the significance of the research, Step 3- Stating limitation, Step 4Presenting recommendation or implication. Both datasets did not show any occurrence of the steps

Table 3. The Frequency of Occurrences of Move

\begin{tabular}{cccccc}
\hline Move & Step & E1 & E2 & I1 & I2 \\
\hline M1 & S1 & - & - & - & - \\
& S2 & $17 \%$ & $17 \%$ & - & - \\
& S3 & - & - & - & - \\
& S4 & $8 \%$ & $8 \%$ & - & $19 \%$ \\
M2 & & $4 \%$ & $8 \%$ & $8 \%$ & $6 \%$ \\
M3 & S1 & $\mathbf{4 \%}$ & $8 \%$ & $8 \%$ & - \\
& S2 & $\mathbf{4 \%}$ & $\mathbf{8 \%}$ & $8 \%$ & - \\
& S3 & $9 \%$ & $\mathbf{8 \%}$ & $42 \%$ & $38 \%$ \\
M4 & & $26 \%$ & $33 \%$ & $17 \%$ & $31 \%$ \\
& S1 & $17 \%$ & $25 \%$ & $17 \%$ & $6 \%$ \\
& S2 & - & - & - & - \\
& S3 & - & - & - & - \\
& S4 & - & - & - & - \\
\hline
\end{tabular}

mentioned earlier.

One interesting point to be discussed is the occurrence of embedded steps in one move, particularly in Move 3. There were combinations of two steps together in Move 3- Method of abstracts written in English, namely Step 2-Describing instrument(s) + Step 1- Describing participants/data sources and Step 3Describing procedure and context + Step 2-Describing instrument(s).

Example 1

Step 2-Describing instrument(s) + Step 1-Describing participants/data sources

The data collection involving 13 fourth-year college students majoring in ELT taking Teaching Practice Course who were supervised by four coordinating teachers serving as supervisors (SP) was by series of five-scale teaching observations, close and open-ended questionnaires, and semistructured interview. [E2, M3, Sentence 11]

Example 2

Step 3-Describing procedure and context + Step 2Describing instrument $(s)$

The study employed a descriptive method with multi-instruments. [E1, M3, Sentence 6] 


\subsection{Move Pattern}

The details concerning move structures of the two sets of abstracts are presented in Table 3. It is assumed that the preferred structures extracted from the study may function as practical guidance for novice writers to construct their abstracts effectively and confidently.

Table 4. Move Pattern Found in Each Abstract

\begin{tabular}{cc}
\hline Abstracts & Organization Pattern \\
\hline E1 & I-P-M-F-C \\
E2 & I-P-M-F-C \\
I1 & P-M-F-C \\
I2 & I-P-M-F-C \\
\hline
\end{tabular}

Table 4 shows the patterns of move found in this study. It was found that all three out of four analyzed abstracts used all five moves in Hyland's (2000) model, especially abstracts written in English. This may confirm that there is already a global agreement and rules regulating the writing of a good and appropriate research abstract. Moreover, the analysis showed that research written in Indonesian also follow this agreement. One particularly interesting point was found in the Introduction move. While it was used frequently in abstracts written in English, the result from the analyzed abstracts written in Indonesian did not show this move as a frequent move. Moreover, in master's thesis abstract written in Indonesian (I1), Introduction move was not used at all.

\subsection{Linguistic Features}

This subsection contains the details concerning the grammatical features concerning tenses, voices, and typology of verbs employed in the moves. Table 5, 6 and 7 provides the results of each category.

Table 5. The Use of Tense in Each Abstract

\begin{tabular}{ccccc}
\hline Tense & E1 & E2 & I1 & I2 \\
\hline $\begin{array}{c}\text { Present } \\
\text { Tense }\end{array}$ & $25 \%$ & $4 \%$ & - & - \\
Past Tense & $75 \%$ & $96 \%$ & - & - \\
\hline
\end{tabular}

Table 5 shows the tense usage. The high numbers of percentage indicated that the past tense was the most frequently used tense in abstracts written in English. The use of past tense in abstracts written in English is about to be presented in Example 3.

\section{Example 3}

Meanwhile, the students found ten strengths of twenty-one items with one weakness. [E1, M4, Sentence 8]

The DPF was adapted from Gibbs (2014) based on works of Bakhtin. (1981, 1984) [E2, M3, Sentence 10]
This finding is supported by some previous studies (Alhuqbani, 2013; Tseng, 2011; Zhang, Thuc, \& Pramoolsook, 2012, as cited in Amnuai, 2019b) that found Method and Product moves used past tense frequently in its delivery. Moreover, Zhang et al. (2012), in their study, found that the present tense is not even

Table 6. The Use of Voice in Each Abstract

\begin{tabular}{ccccc}
\hline Tense & E1 & E2 & I1 & I2 \\
\hline $\begin{array}{c}\text { Active } \\
\text { Voice }\end{array}$ & $83 \%$ & $63 \%$ & $58 \%$ & $63 \%$ \\
$\begin{array}{c}\text { Passive } \\
\text { Voice }\end{array}$ & $17 \%$ & $42 \%$ & $42 \%$ & $38 \%$ \\
\hline
\end{tabular}

used at all in the Method move in Vietnamese agricultural RA abstracts (Amnuai, 2019b). A noticeable difference in the use of tense is that abstracts written in Indonesian did not use any of the tense, since the language of Indonesia did not have tense indicators in its linguistic features. This point shows a significant difference between the two languages.

As shown in Table 6, there is a significant similarity between the two languages and each level of abstracts. It is found that active voice was the frequent voice used in each of the abstracts. Generally, texts are easier to understand when they are in active voice (Lorés, 2004; Swales, 1990, as cited in Amnuai, 2019b). This could mean that the authors tried to emphasize the agent rather than the action being performed. Examples of voice usage are presented below.

Example 4

The study employed a descriptive method with multi-instruments. [E1, M1, Sentence 6]

Therefore, the preliminary study's findings argue for a need to utilize dialogic feedback process to solve the aforementioned problems. [E2, M1, Sentence 8]

Penelitian tindakan kelas ini bersifat kolaboratif yang melibatkan guru sebagai peneliti. [I1, M3, Sentence 6]

Mahasiswa memberi respons yang positif atas model pembelajaran ini. [I2, M4, Sentence 14]

Example 5

Perceived by the teachers, the textbook had five strengths and nine weaknesses of thirthythree items of a Grant's good textbook (E1, M4, Sentence 7)

The feedback provision on their teaching in the dialogs with their supervisor had been considered confusing and unclear. [E2, M1, Sentence 3] 
Penelitian ini dilaksanakan dalam lima bulan mulai bulan Agustus 2008 sampai dengan bulan Januari 2009. [I1, M3, Sentence 2]

Analisis deskriptif digunakan untuk menganalisis rancangan model pembelajaran dan berbagai konten film yang memiliki muatan ekspresi keaktoran tertentu. [I2, M3, Sentence 8]

As showed above, Example 4 demonstrates the use of active voice, while Example 5 presents the employment of passive voice.

Table 7. The Use of Verbs in Each Abstract

\begin{tabular}{ccccc}
\hline Tense & E1 & E2 & I1 & I2 \\
\hline Action Verb & $100 \%$ & $42 \%$ & $67 \%$ & $81 \%$ \\
$\begin{array}{c}\text { Helping } \\
\text { Verb }\end{array}$ & - & $50 \%$ & $8 \%$ & $13 \%$ \\
$\begin{array}{c}\text { Linking } \\
\text { Verb }\end{array}$ & - & $8 \%$ & $25 \%$ & $6 \%$ \\
\hline
\end{tabular}

Table 7 presents the use of verbs in each abstract. In terms of verb usage, action verb dominated the occurrence $(=/>50 \%$ in all abstracts except for E2), predominantly in E1, as shown in the excerpts.

Example 6

The study investigated strengths and weaknesses and teacher's teaching strategies and learner's learning strategies to encounter the weaknesses of the textbook in use. [E1, M2, Sentence 4]

To encounter weaknesses of the textbook in use, the teachers employed Spratt et al.'s teaching strategies. [E1, M4, Sentence 9]

In E2, however, the occurrence of helping verb was higher than action verb (50\%).

\section{Example 7}

These factors could create sense of identity and self-esteem. [E2, M4, Sentence 17]

Second, teaching competence improvement could be reached when dialogic feedback process is understood, timely, and specific by supervisors and prospective teachers as a holistic and scaffolded in Tutorials and Assessments. [E2, M4, Sentence 21]

\section{CONCLUSION}

The main conclusions can be summarized on the basis of the study of the two data sets. In both abstracts written in English, Introduction and Findings moves are the most common. Method move was a frequent move in abstracts written in Indonesian. M4 is the most manifested step for abstracts written in English. This may imply the intention of the author to emphasize the product of his/her study.
However, this move does not have any steps at all. Method moves, however, often occurred in abstracts written in Indonesian, mostly in Step 3-Describing product and context. Interestingly, the two sets of abstracts show similarity in Move 1, Step 1- Arguing for topic significance, Step 3-Defining key term(s); Move 5, Step 2-Evaluating the significance of the research, Step 3-Stating limitation, Step 4- Presenting recommendation or implication. The two datasets did not display any occurrence of the steps described above. It was also found that all three of the four abstracts studied used all five moves of Hyland's (2000) model, in particular, abstracts written in English. This may confirm that there is already a global consensus and rules governing the writing of a good and sufficient research abstract. Moreover, the study has shown that abstracts written in Indonesian also meet this agreement. Past tense was the most commonly used in abstracts written in English. A notable difference in the usage of tense is that abstracts written in Indonesian did not use any of the tense as Indonesian did not have a tense indicator in its linguistic features. This point suggests a major difference between the two languages. In terms of voice and verb usage, both datasets show significant similarities with active voice and action verb as the most frequently used linguistic features in each abstract. Despite the small scale of sample used in this study, it is believed that the findings could show the characteristics of English and Indonesian languages that could help students write their abstracts. However, since this analysis is focused on a limited number of samples, it is difficult to generalize the findings to all situations. A larger number of corpora will have a better picture of the rhetorical and grammatical features of abstracts in English and Indonesian.

\section{ACKNOWLEDGMENTS}

This study was supported by a grant from the Research and Community Service Unit, Indonesia University of Education. The authors would like to express appreciation for all the support provided.

\section{REFERENCES}

Alhuqbani, M. N. (2013). Genre-based analysis of Arabic research article abstracts across four disciplines. Journal of Educational and Social Research, 3(3), 371-382.

https://doi.org/10.5901/jesr.2013.v4n3p371

Amnuai, W. (2019a). Analyses of rhetorical moves and linguistic realizations in accounting research article abstracts published in international and Thai-based journals. Sage Open, 9(1), 1-9. https://doi.org/10.1177/2158244018822384

Amnuai, W. (2019b). Rhetorical move structures and linguistic realizations of abstracts in ICT research articles and master's theses. Sage Open, 8(1), 157- 
184. https://so05.tcithaijo.org/index.php/MFUconnexion/article/view/2 41189

Hardjanto, T. D. (2017). Common discourse patterns of cross-disciplinary research article abstracts in English. Jurnal Humaniora, 29(1), 72-84. https://doi.org/10.22146/jh.v29i1.22567

Hyland, K. (2000). Disciplinary discourses: Social interactions in academic writing. Longman.

Hyland, K. (2004). Disciplinary discourses: Social interactions in academic writing. The University of Michigan Press.

Kafes, H. (2012). Cultural traces on the rhetorical organization of research article abstracts. International Journal on New Trends in Education and Their Implications, 3(3), 207-220. http://www.ijonte.org/FileUpload/ks63207/File/20. kafes.pdf

Kurniawan, E., Lubis, A. H., Suherdi, D., \& Danuwijaya, A. A. (2019). Rhetorical organization of applied linguistics abstracts: Does Scopus journal quartile matter? GEMA Online® Journal of Language Studies, 19(4), 184-202. https://doi.org/10.17576/gema-2019-1904-10

Lorés, R. (2004). On RA abstracts: From rhetorical structure to thematic organisation. English for Specific Purposes, 23(3), 280-302. https://doi.org/10.1016/j.esp.2003.06.001

Male, H. (2018). A structural move analysis of abstracts in undergraduate theses: A case study at Universitas Kristen Indonesia. KnE Social Sciences, 3(9), 284294. https://doi.org/10.18502/kss.v3i9.2690

Mohsenzadeh, H. (2013). Rhetorical move structure of literature book prefaces in English and Persian. Mediterranean Journal of Social Sciences, 4(4), 317-323. https://doi.org/10.5901/mjss.2013.v4n4p317

Nikpei, H. (2016). Rhetorical moves of abstracts written by TEFL Students and molecular biology graduate students- A comparative study. International Journal of English Language and Translation Studies, 4(4), 172-179. http://www.eltsjournal.org/archive/Value4\%20Issu e4/16-4-4-16.pdf

Pho, P. D. (2008). Research article abstracts in applied linguistics and educational technology: A study of linguistic realizations of rhetorical structure and authorial stance. Discourse studies, 10(2), 231-250. https://doi.org/10.1177/1461445607087010
Suntara, W., \& Usaha, S. (2013). Research article abstracts in two related disciplines: Rhetorical variation between linguistics and applied linguistics. English Language Teaching, 6(2), 84-99. https://doi.org/10.5539/elt.v6n2p84

Suryani, F. B., \& Rismiyanto, R. (2019). Move analysis of the English bachelor thesis abstracts written by Indonesians. Prominent, 2(2). https://doi.org/10.24176/pro.v2i2.4229

Swales, J. M. (1990). Genre analysis: English in academic and research settings. Cambridge University Press.

Swales, J. M. (2004). Research genres: Explorations and applications. Cambridge University Press.

Tseng, F. P. (2011). Analyses of move structure and verb tense of research article abstracts in applied linguistics journals. International journal of English linguistics, $\quad 1(2), \quad 27-39$. https://doi.org/10.5539/ijel.v1n2p27

Vathanalaoha, K., \& Tangkiengsirisin, S. (2018). Genre analysis of experiment-based dental research article abstracts: Thai and international journals. $3 \mathrm{~L}$ : Language, Linguistics, Literature, 24(3), 1-14. https://doi.org/10.17576/31-2018-2403-01

Xiao, R., \& Cao, Y. (2013). Native and non-native English abstracts in contrast: A multidimensional move analysis. Belgian Journal of Linguistics, $27(1)$, 111-134. https://doi.org/10.1075/bj1.27.06xia

Zamani, G., \& Ebadi, S. (2016). Move analysis of the conclusion sections of research papers in Persian and English. Cypriot Journal of Educational Sciences, $\quad 11(1), \quad 9-20$ https://doi.org/10.18844/cjes.v11i1.344

Zhang, B., Thuc, Q. B. T., \& Pramoolsook, I. (2012) Moves and linguistic realizations: English research article abstracts by Vietnamese agricultural researchers. Asian ESP Journal, 8(2), 126-149. https://www.asian-esp-journal.com/wpcontent/uploads/2013/11/Volume-83.pdf\#page $=126$ 